\title{
7. UNDERWAY SURVEYS, LEG 34
}

\section{J.M. Ade-Hall, Department of Geology, Dalhousie University, Halifax, Nova Scotia, Canada}

\section{INTRODUCTION}

Leg 34 of the Deep Sea Drilling Project extended for approximately $8000 \mathrm{~km}$ from Tahiti to Callao, Peru. On this leg, Glomar Challenger crossed several major features of the southeast Pacific, and continuous geophysical measurements were made across these features (Figure 1). The major features of tectonic interest crossed by the track were the Tuamotu Rise, the East Pacific Rise, the Bauer Deep, the Galapagos Rise, and the Peru-Chile Trench. In the sections that follow, the bathymetry, sediment distribution, and magnetic anomaly patterns associated with these features are discussed, together with a number of more local features. Since only information from a single track is available, interpretation is hampered by lack of knowledge of whether features are two or three dimensional and whether they are of local or regional significance. For these reasons the contribution to our knowledge of the area is largely in testing the results of the analysis of regional bathymetric and magnetic surveys made by other groups. From the viewpoint of Leg 34 studies, the underway survey data are valuable in providing a framework for detailed surveys and other results from the drilling sites.

\section{SURVEY METHODS AND EQUIPMENT}

Navigation was entirely by satellite fixes. A $12-\mathrm{kHz}$ transducer was used for echo sounding and seismic reflection measurements were made with $82-\mathrm{cc}\left(5\right.$ in. $\left.^{3}\right)$ and 655-cc (40 in. ) airguns, fired in tandem, and received via a single channel array. The reflection profiles were recorded concurrently on two recorders, one set to show the full time range being scanned and the other the small time interval during which reflections were being observed. The magnetic field was recorded using a small proton precession magnetometer.

In addition to the routine logging of geophysical and navigational information, sea-floor topography and magnetics were plotted against time by the technician on watch. This extra task carried out by the electronics laboratory personnel provided a quick and exact overall view of the track geophysics while underway and has proven most useful in presenting the general properties of the ocean crust along the ship's track.

\section{SEDIMENT THICKNESS AND BASEMENT TOPOGRAPHY}

Figure 1 shows the track of Glomar Challenger from Tahiti to Callao, and Figure 2 shows the smoothed sediment thickness and basement topography profiles along the track. Figure 2 has been prepared by plotting average values for $100-\mathrm{km}$ intervals over the $8000-\mathrm{km}$ track. In order to match synthetic magnetic profiles, etc with observed profiles, most distances differ slightly from track distances, being corrected to values for "best fit" sea-floor spreading flow lines. The division of the ocean floor into distinct tectonic provinces is clear in Figure 2 (B).

The eastern flank of the pedestal of Tahiti, at 0 to 200 $\mathrm{km}$, is nearly sediment free, which is consistent with the Neogene age and steep slope of the volcanic edifice.

The Tuamotu Rise extends from 200 to $1200 \mathrm{~km}$ along the profile of Figure 2 (B). Sharp topographic breaks separate it distinctly from the Tahiti pedestal to the west and from oceanic crust associated with spreading on the Galapagos Rise to the east (Figure 3). The thick, frequently ponded sediments associated with the Tuamotu Rise also distinguish it from the neighboring tectonic provinces. At an assumed average velocity of 1.55 $\mathrm{km} / \mathrm{sec}$, sediment thickness across the Tuamotu Rise averages close to 150 meters compared with a negligible thickness on the Tahiti Pedestal and an average of 40 meters on the oldest part of the Galapagos Rise crust. Rather little is known of the history of the Tuamotu Rise. Coralline atolls form the only subaerial expression of the rise. Two DSDP sites were located within the rise: Site 76 is found on the northern flank some $100 \mathrm{~km}$ from Ake and Manihi atolls (Hays et al., 1972). Penetration here was limited to 30 meters by the presence of a chert horizon. The thin cored interval contains a number of turbidite horizons with calcareous algae, coral sclerites, mollusc fragments, and abraded reefal debris. It seems very probable that these turbidite layers were derived by means of currents from the nearest islands of the archipelago, and, from their fossil content, imply an Eocene minimum age for the islands. Site 318, drilled on the northern end of the rise, has early Eocene sediments at a depth of 745 meters subbottom, with the termination of flow volcanism estimated at a minimum age of 50 m.y. (Schlanger, Jackson, et al., 1974). The mode of formation of the crust of the Tuamotu Rise is uncertain. Morgan (1972) and others have suggested a mantle hotspot source, but it seems that other modes cannot be excluded.

The East Pacific Rise (Figure 4) extends as a topographic expression from the foot of the Tuamotu Rise, at close to $1200 \mathrm{~km}$, to the Bauer Deep at $4800 \mathrm{~km}$ on the profile of Figure 2 (B). A gradient break at about $3000 \mathrm{~km}$ is interpreted here as marking the contact between oceanic crusts generated at the Galapagos Rise and East Pacific Rise but could also mark a transform fault. However, in either event, the time gap implied by the break is not evident in the sediment distribution plot (Figure 2 [A]). It has been suggested that the active spreading axis of the East Pacific Rise jumped westwards by some $1000 \mathrm{~km}$ at about 6 to 9 m.y. B.P. (Herron, 1972; Anderson and Sclater, 1972; Rea, in press). The observed bathymetry suggests, however, that a more complicated evolutionary model is required for 


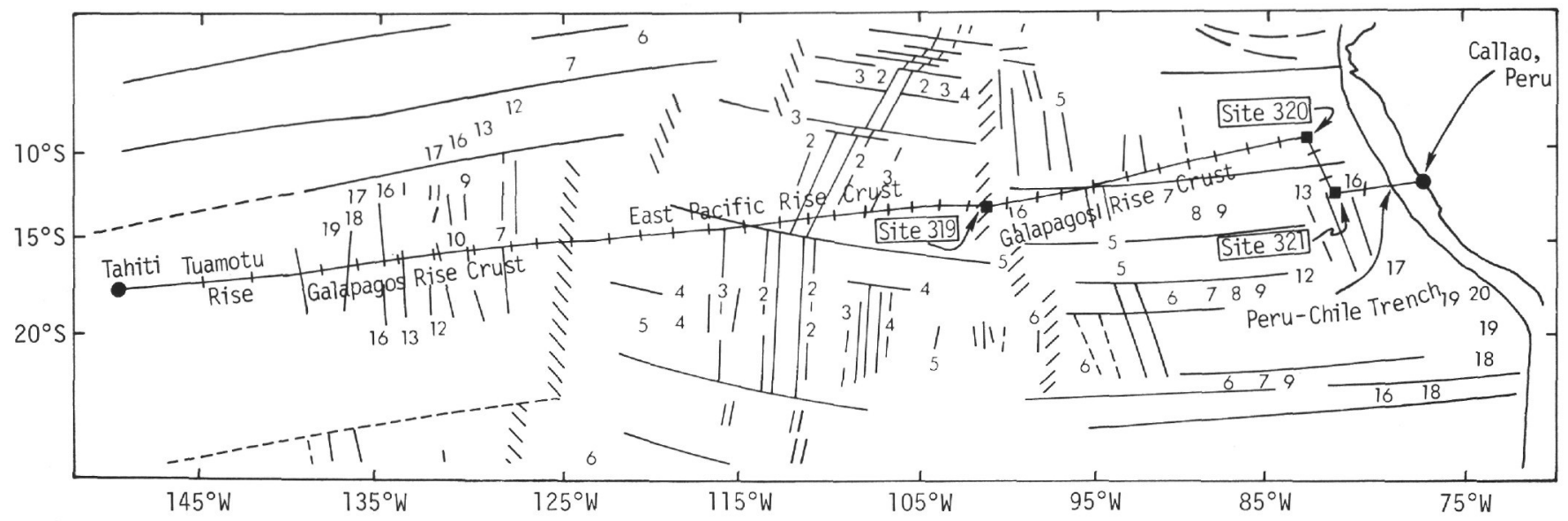

Figure 1. Track chart for Glomar Challenger on DSDP Leg 34 (with acknowledgment to the Geological Society of America, Inc. and Pitman et al. 1974).

this segment of oceanic crust, and the problem is discussed at length in a later section. In this simple model of ridge jumping the crust between the foot of the Tuamotu Rise at $1200 \mathrm{~km}$ and $3000 \mathrm{~km}$ was possibly formed at the Galapagos Rise axis, now located within the Nazca plate at $5700 \mathrm{~km}$. The magnetic anomalies shown on Figure 1 support this interpretation in that lineations for anomalies 6 to 19 are rotated by a small but significant angle from anomalies 1 to 3 or $3^{\prime}$, which were formed at the present spreading center. The presence of anomaly 19 , near the foot of the Galapagos Rise (Figure 1), suggests an age a little over 47 m.y. for the oldest Galapagos Rise crust at $1200 \mathrm{~km}$ on the profile of Figure 2. It seems then that the oldest Galapagos Rise crust and the Tuamotu Rise crust were formed at a similar, Eocene time.

The sediment cover of the East Pacific and Galapagos rises is strictly limited, with average values for $100-\mathrm{km}$ intervals over the older segments of 70 meters or less (Figure 2 [A]). A broad zone of about $400 \mathrm{~km}$ width near the present spreading axis is essentially sediment free. Comparison of the sediment thickness and bathymetric profiles of Figure 2 indicates that the sediment-free zone is offset to the east by $200 \mathrm{~km}$ with respect to the topographic axis. An offset in the same sense of some $400 \mathrm{~km}$ occurs on the Galapagos Rise crest. The extension of the zone with very low sediment cover to the east of the present spreading axis may be explained in terms of a combination of increased solution of carbonates to the east of the spreading axis (Edmond, 1974) and astward-directed bottom currents (Lonsdale, personal communication). In this context it is noted that the lower sediments of the Bauer Deep or Basin, at the foot of the present spreading rise, are distinctly ponded (Figure 5).

The Bauer Deep lies east of the present spreading axis and separates it from the Galapagos Rise crest. Figure 5 shows details of the bathymetry and sediment fill in the Bauer Deep. Considerable local ponding of the lower transparent sediments is evident, while the upper sediments are clearly draped over the topography. The presence of ponded sediments suggests that erosion and reworking may have taken place. This allows the possibility that a significant time interval separates the ages of basement and the oldest sediments at some locations. It is of considerable importance to decide whether Site 319, which is situated within the Bauer Deep, is located in crust formed at the Galapagos Rise or at the present East Pacific Rise. According to Anderson and Sclater (1972) the crust of the Bauer Deep was formed at the Galapagos Rise whereas Mammerickx et al. (1975), using the position of the eastward termination of the Marquesas Fracture Zone (Pautot and Dupont, 1974) as a guide, place the East Pacific Rise-Galapagos rise boundary within the basin a little to the west of Site 319 . This point will be considered again in this paper when segments of the bathymetry along the Glomar Challenger track are fitted to Sclater and Francheteau (1970) type depth versus age curves.

The Galapagos Rise, an extinct spreading ridge within the Nazca plate, is clearly seen in Figures 2 (B) and 6. The depth of the crest at 3600 meters compared to 2800 meters for the East Pacific Rise crest suggests the antiquity of this rise and, from a combination of magnetic and bathymetric evidence, Herron (1972) and Anderson and Sclater (1972) date the jump in activity to the present rise crest at 6 m.y.B.P. while Rea (in press) suggests that 8-9 m.y. is a better figure at the latitude of the Glomar Challenger track. The absence of measurable sediment cover directly to the east of the Galapagos Rise is rather puzzling if volcanic activity completely ceased at this time. Bottom current activity and differential solution of carbonates do not seem applicable as explanations for the sediment-free zone and its eastward offset with respect to the rise axis. An alternative explanation is that occasional volcanism, extending from 6-9 m.y.B.P. to the present, has blanketed the sediment cover, but is insufficient in magnitude to produce detectable tectonic or magnetic effects. Site 320 lies on the eastern flank of the Galapagos Rise and the age of the basal sediments of 26-30 m.y.B.P. at this site provides a constraint on the history of the rise.

Between Sites 320 and 321 the track of Glomar Challenger is nearly along the strike of crust generated at the Galapagos Rise (Figure 1). The features of interest on this segment of the track are two large fault zones, $160 \mathrm{~km}$ apart, one or both of which presumably are to be identified with the Mendaña Fracture Zone. The 

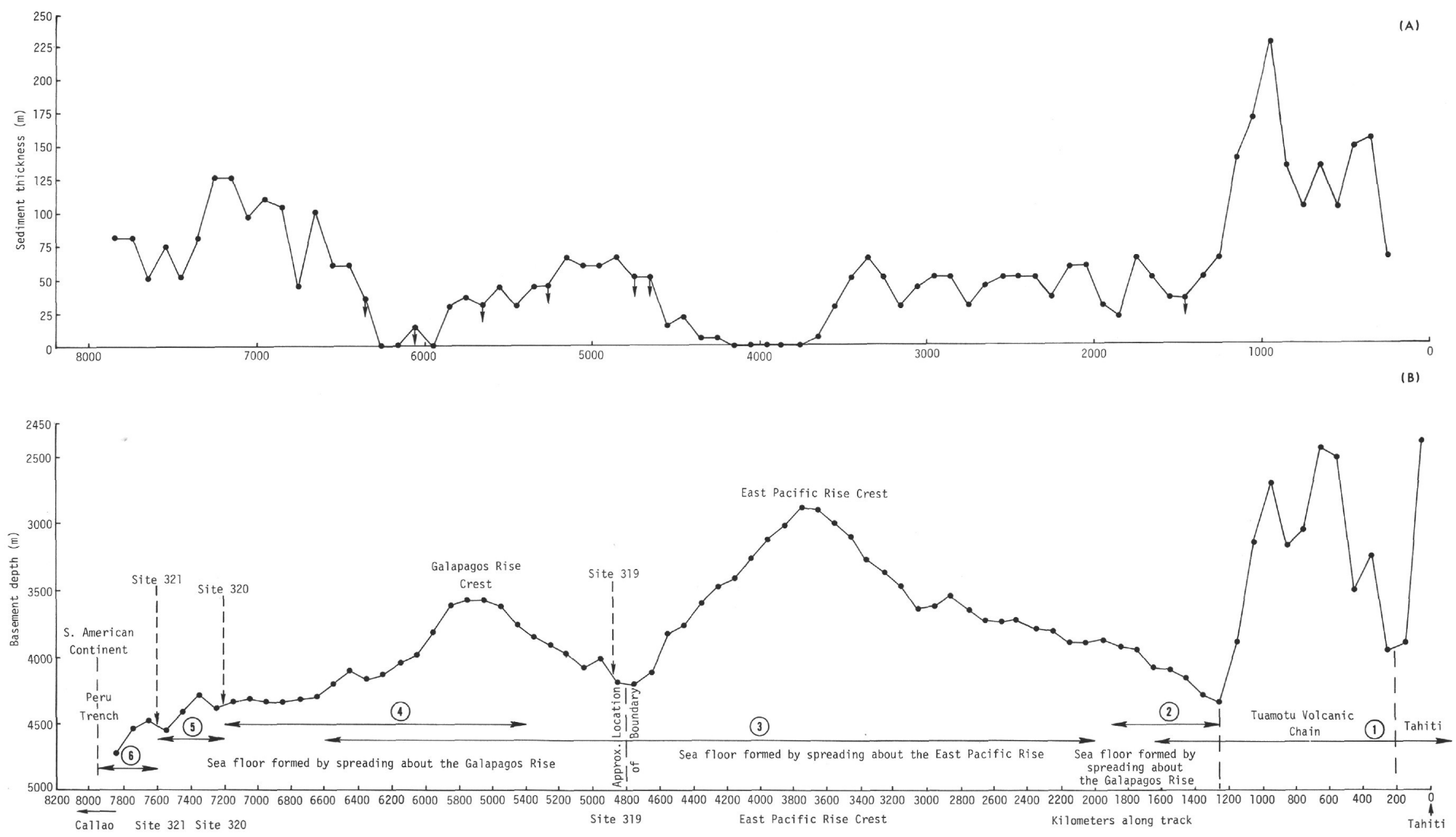

Figure 2. Sediment thickness and bathymetry. Average values for 100-km intervals along the track of DSDP Leg 34. 


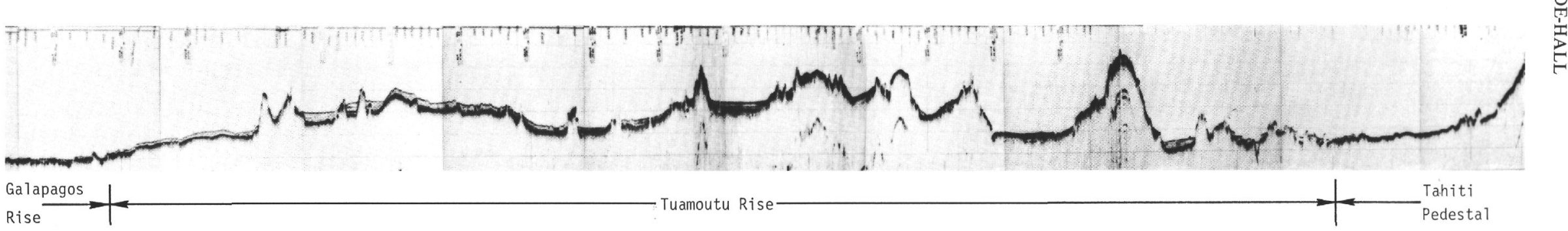

Figure 3. Seismic reflection profile across the Tuamotu Rise.

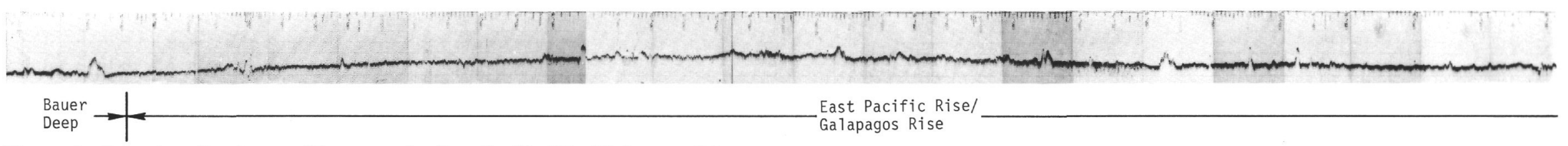

Figure 4. Seismic reflection profile across the East Pacific Rise/Galapagos Rise.

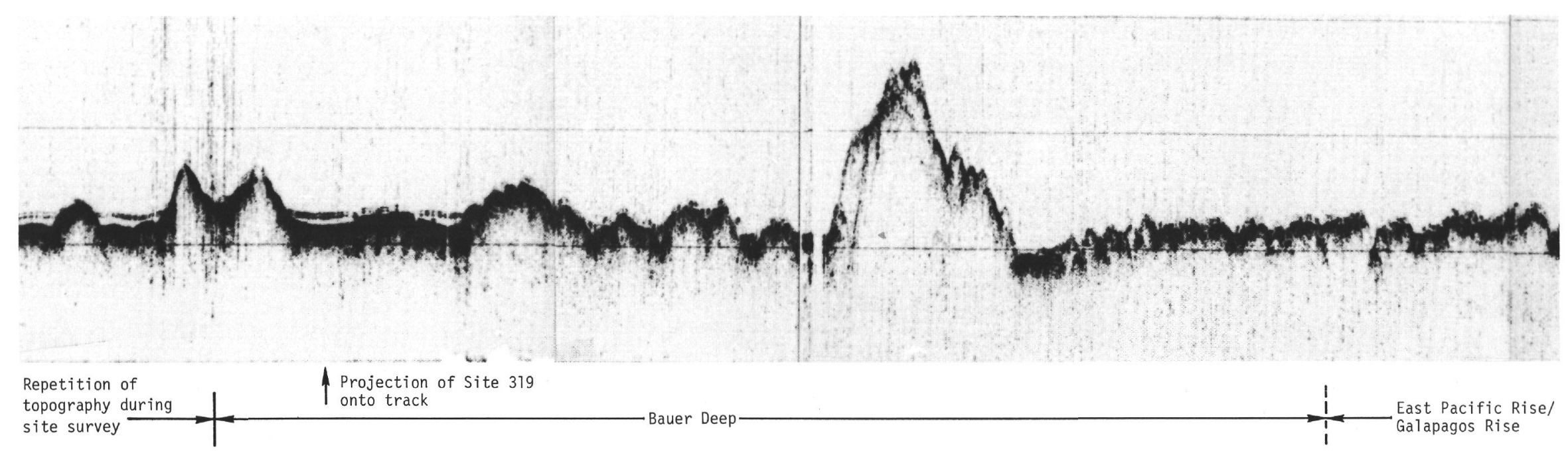

Figure 5. Seismic reflection profile across the Bauer Deep. 


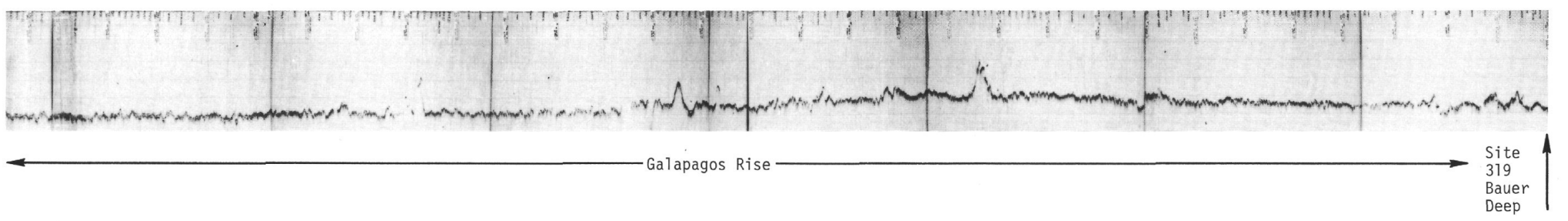

Figure 6. Seismic reflection profile across the Galapagos Rise crest.

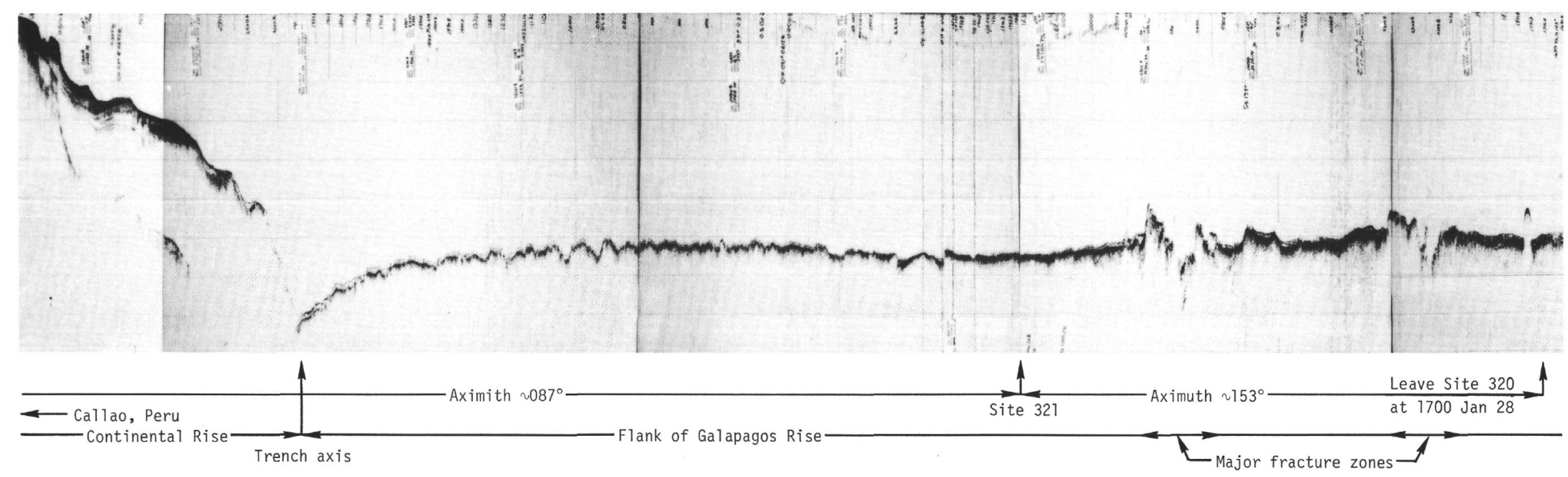

Figure 7. Seismic reflection profile across the Galapagos Rise, the Mendana Fracture Zones the Peru-Chile Trench, and the Peruvian continental margin. 

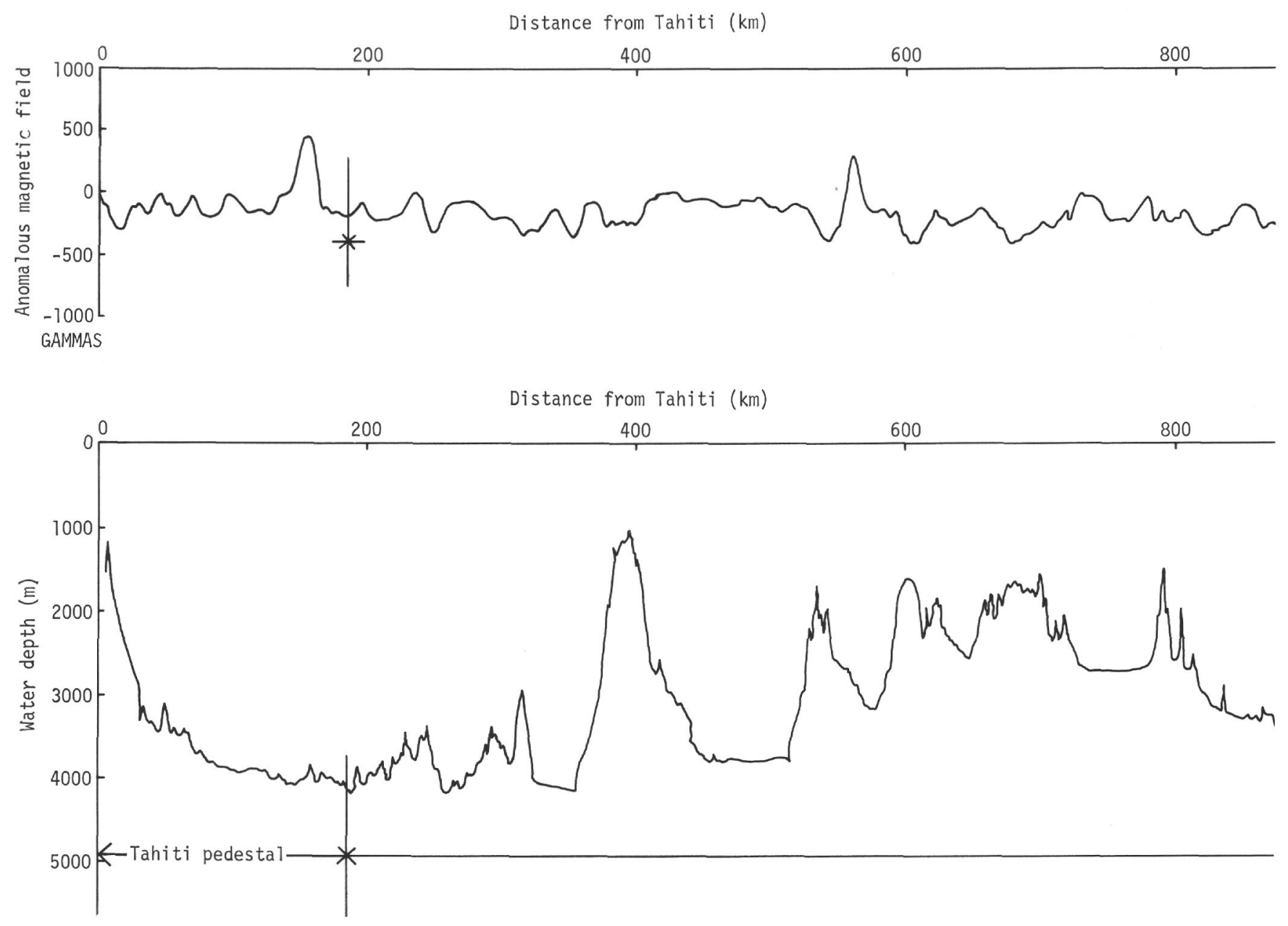

Figure 8. Magnetics and bathymetry across the Tahiti Pedestal, the Tuamotu Rise, and the western flank of the East Pacific Rise (consisting of crust formed at the Galapagos Rise) (with acknowledgment to the Underway data processing group, SIO).

fault zones are impressive features, extending, respectively, for $35 \mathrm{~km}$ and $44 \mathrm{~km}$ in cross-section and 900 meters and 1100 meters in maximum relief.

From Site 321 to Callao the track of Glomar Challenger was perpendicular to the structural trend, as it was from Tahiti to Site 320. The major tectonic feature of this segment is the Peru-Chile trench (Figure 7 ), which in this area separates oceanic crust of the Nazca plate formed at the Galapagos Rise from the continental crust of the American plate. At the point of crossing of the trench axis the water depth was 5800 meters. Oceanic basement could be followed for close to $1 \mathrm{~km}$ beneath the landward wall of the trench, a feature interpreted elsewhere as evidence for the reality of the subduction process (Chase and Bunce, 1969; Holmes et al., 1972). The structure of the sediment pile on the landward wall of the trench suggests major slumping as a means of sediment transport from the continental shelf.

\section{MAGNETIC ANOMALY PROFILES}

The track of Glomar Challenger during Leg 34 lay within equatorial latitudes, which, where the strike of a spreading axis approaches north-south, are the most difficult part of the earth's surface for magnetic anomaly identification. For this reason there was little expectation that crustal sections or drilling sites could be dated by reference to the geomagnetic polarity-time scale of Heirtzler et al. (1968) and others. In fact, firm anomaly identification was only possible in the vicinity of Site 321. Herron's (1972) estimates of spreading rates indicate that very rapid spreading has and is taking place along the line of the track, with half rates of between 5 and $15 \mathrm{~cm} / \mathrm{yr}$.

Total magnetic field data were reduced in two ways. For the track segment from Tahiti to the western margin of crust generated at the Galapagos Rise, the compilation produced by the underway data processing group at Scripps Institution of Oceanography was used. Here the IGRF has been subtracted from the observed field values and combined plots of anomalous magnetic field and bathymetry produced (Figure 8). For the remaining part of the track to Callao magnetic anomalies were separated from the core-generated field using the underway data plot. Here linear field gradients were fitted by eye to successive $300-\mathrm{km}$ track sediments. This was done both since the IGRF fits rather poorly over some parts of the track and to obtain the core-generated contribution to the observed field (Figure 9). Although the track gradually approached the equator from Tahiti to 

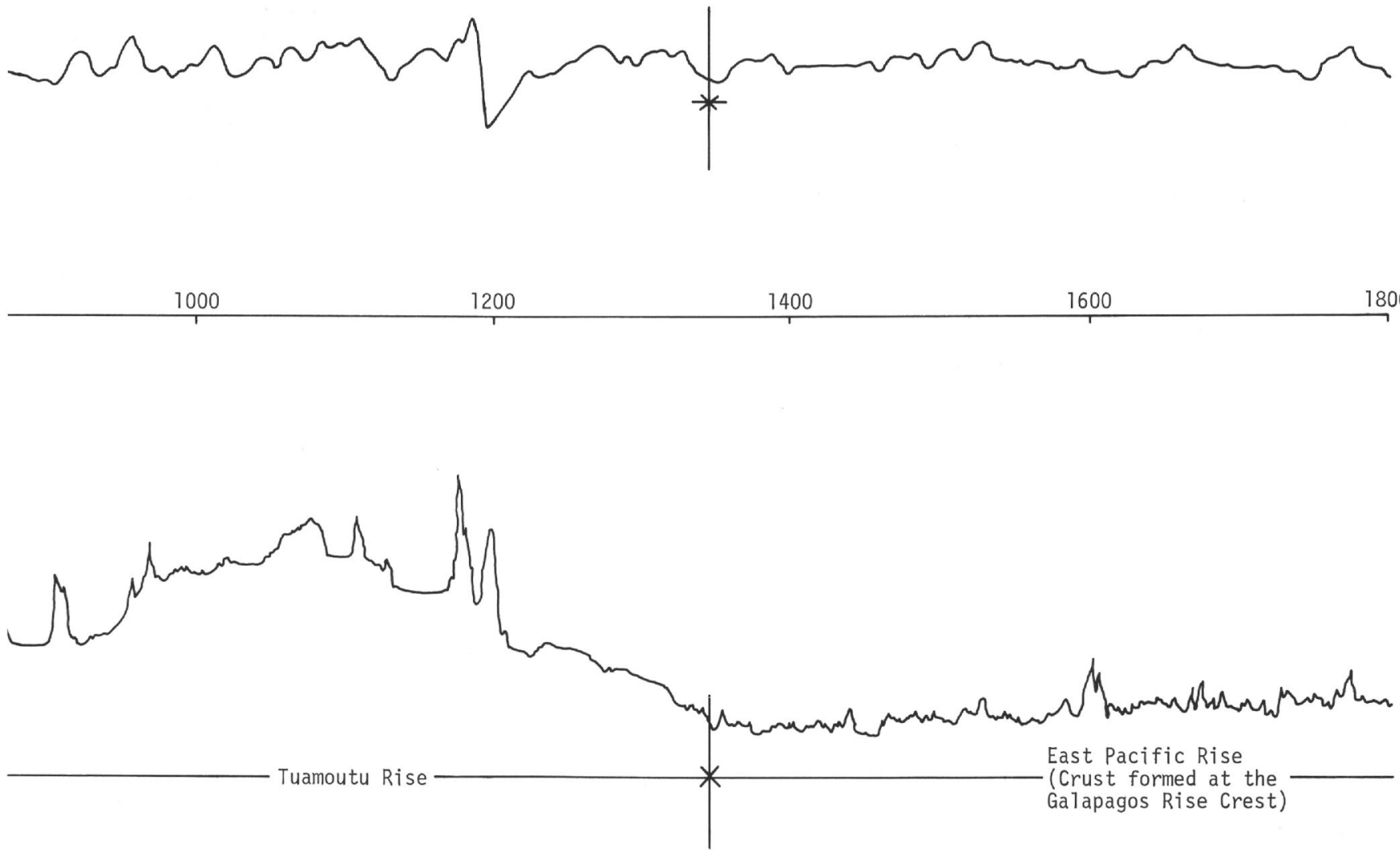

Figure 8. (Continued).

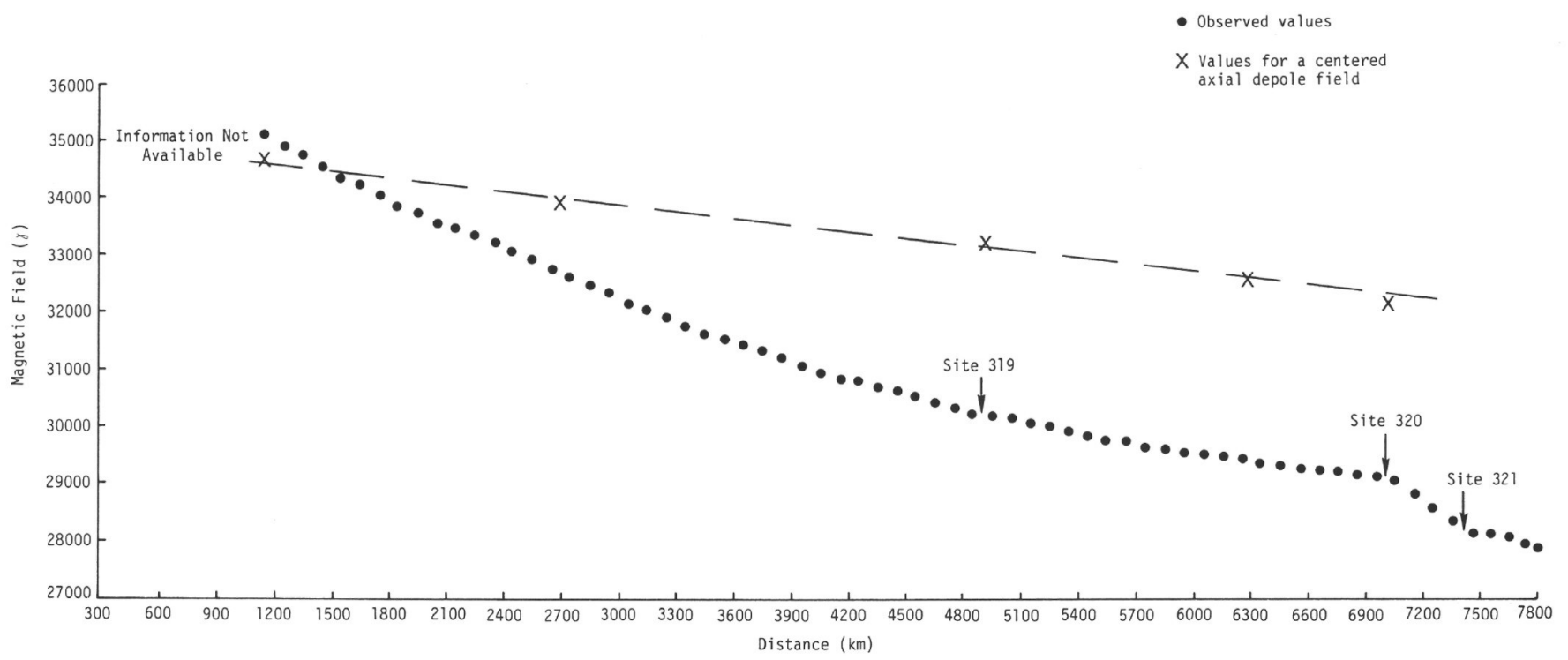

Figure 9. Core-generated contribution to the observed magnetic field along the track of DSDP Leg 34. 
Site 320 , the core-generated field decreased much more rapidly than would be anticipated for a centered axial dipole source. Additionally, the field decreased between Sites 320 and 321, where the ship was traveling away from the equator. Both of these observed features express the approach of the ship towards one of the small number of major nondipole anomalies of the geomagnetic field, in this case, the anomaly with minimum value of less than $25,000 \gamma$, against an anticipated value of excess of $37,000 \gamma$, centered near Sao Paulo, Brazil.

From Tahiti to the western margin of crust possibly generated at the Galapagos Rise, typical oceanic anomalies occur (Figure 8), with a noticeable increase in wavelength at the Tuamotu Rise-Galapagos Rise boundary. The longer wavelength anomalies of the Galapagos Rise crust are distinctly smaller in amplitude than the Tuamotu Rise anomalies, an effect which must largely be the result of the deeper water over the East Pacific Rise flank. Peak-to-peak anomalies in excess of $500 \gamma$ occur over the Tuamotu Rise. Some of these are likely to be the result of polarity variations within the volcanic basement of the rise, since correlation with topographic features is poor except for the seamounts at $1200 \mathrm{~km}$ and perhaps at $540 \mathrm{~km}$. The 3000 -meter peak at $380 \mathrm{~km}$ is notable in having little or no magnetic expression at the surface. The absence of a magnetic anomaly over this peak can only partly be explained by the presence of a 200-meter-thick sediment cap (Figure 3). It is necessary to appeal to fortuitous crossing of a point of reflection in a large anomaly, to the presence of extensive alteration or to a record of polarity reversals within the peak to explain its low magnetic signal.

The lower western flank of the present East Pacific Rise, to the boundary with the Tuamotu Rise, was probably generated at the Galapagos Rise. According to Pitman et al. (1974) anomalies 6 to 20 can be identified within the area of the track (Figure 1). Figure 10 shows the observed profile together with a profile for field inclinations of $\pm 31^{\circ}$, the value for a centered axial dipole field at this latitude, and a spreading half rate of 5.3 $\mathrm{cm} / \mathrm{yr}$, estimated from the spacing of anomalies in Figure 1. Clearly synthetic and observed profiles fail to match and although the synthetic profile has probably been calculated for a shallower Layer 2 than the observed profile, we must still assume that one or more of the assumptions (crustal age, spreading rate, anomaly identification, magnetization azimuth, or inclination) are incorrect. From spreading rates estimated for the vicinity of the Galapagos Rise crest, it would seem that this spreading rate of $5.3 \mathrm{~cm} / \mathrm{yr}$ is low by approximately a factor of two, which must be an important factor in the mismatch.

The observed magnetic anomaly profile for crust formed by the East Pacific Rise, the Bauer Deep, and the Galapagos Rise crest is shown in Figure 11a. The notable features of the observed magnetics are the lack of obvious symmetry about either East Pacific Rise or Galapagos Rise crests and the sharp difference in the character of the anomalies between the interval from $3050 \mathrm{~km}$ to $4020 \mathrm{~km}$ and the remainder of this segment of the track.
The general lack of symmetry and lack of correlation with the synthetic profiles of Figure $11 \mathrm{~b}$ are characteristic features of equatorial magnetic profiles and can be expected where magnetization is close to the horizontal, and geological trends are close to the magnetic meridian, of three-dimensional geological and bathymetric features. However, the abrupt change in the character of the anomalies at 3050 and $4020 \mathrm{~km}$ requires another explanation. Within this interval the anomalies average more than a factor of two greater in amplitude and have shorter average wavelengths than most of the remainder of the track segment. The simplest explanation for both of these differences lies in the different origins of the crust between 3050 and $4020 \mathrm{~km}$ and elsewhere. It seems that this $970-\mathrm{km}$ crustal section formed at the presently active East Pacific Rise crest and the remainder of the crust at the Galapagos Rise crest. This is evident from the inclusion of the East Pacific Rise crest in this section (Figure 2b) and the general agreement of the boundaries of this segment with the result of regional surveys, summarized in Herron (1972), Anderson and Halunen (1974), and elsewhere. Figure 12 shows the bathymetry along the track in a slightly different format from that of Figure $2 b$, together with Sclater-Francheteau type model profiles fitted as indicated. The boundaries of the East Pacific Rise generated crust from Figure 12 as marked on Figure 11a match closely on the west and less well on the west to the boundaries of the $970-\mathrm{km}$ section with high amplitude, short wavelength magnetic anomalies. Clearly the sharp distinction of magnetic zones along the Glomar Challenger track, which crosses the East Pacific Rise crest at $14^{\circ} \mathrm{S}$, is typical of a considerable area since parallel profiles in Herron (1972) (Figures $7 \mathrm{c}$ at $5.6^{\circ} \mathrm{S}$ and $7 \mathrm{~d}$ at $9.2^{\circ} \mathrm{S}$ ) show identical divisions.

The enhanced amplitude of anomalies between 3050 and $4020 \mathrm{~km}$ could be explained in several ways, such as relatively shallow water depth, the different geometry of fault bounded regions leading to rotation of basement strike away from the meridian, basement magnetization in a stronger geomagnetic field, and petrologic contrasts. The last of these possibilities has an interesting potential of explaining the observations. Ridge jumping to the present location at 6 to $9 \mathrm{~m} . \mathrm{y}$. ago has resulted in sharp crustal age breaks at 3050 and $4020 \mathrm{~km}$. Over a presumably short (but unknown) distance at each of these points, crustal age changes from 6 to 9 m.y. (East Pacific Rise crust) to 16 m.y. (Galapagos Rise crust). Now, from Irving et al. (1970), Ade-Hall et al. (Rock Magnetism of Basalts, this volume), and others it is apparent that the intensity of magnetization of layer 2 basalts is strongly related to the degree of low temperature alteration, resulting from seawater circulation through the upper part of the oceanic crust, with intensity decreasing with increasing alteration. It is reasonable to suppose that the additional 7 to $10 \mathrm{~m}$.y. of action of this alteration process on the Galapagos Rise crust has reduced the average crustal magnetization to well below the value for 6 to 9 m.y. old crust; hence the sharp change in anomaly amplitudes. Strong magnetization for crust generated along the East Pacific Rise is confirmed by the coincidence of the largest anomaly in 

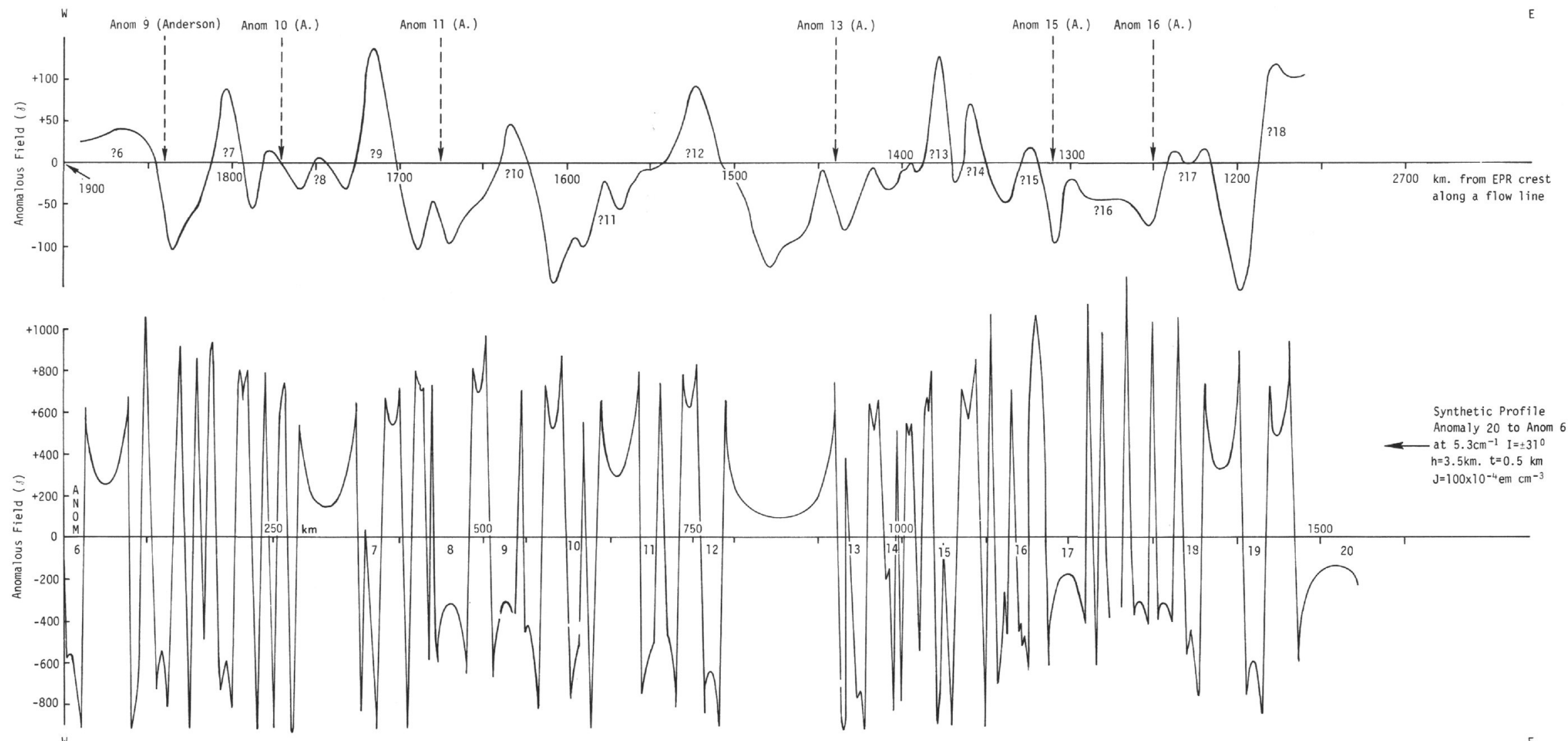

Figure 10. Observed and synthesized magnetic anomaly profiles for the lower western flanks of the East Pacific Rise, consisting of crust generated at the Galapagos Rise. 


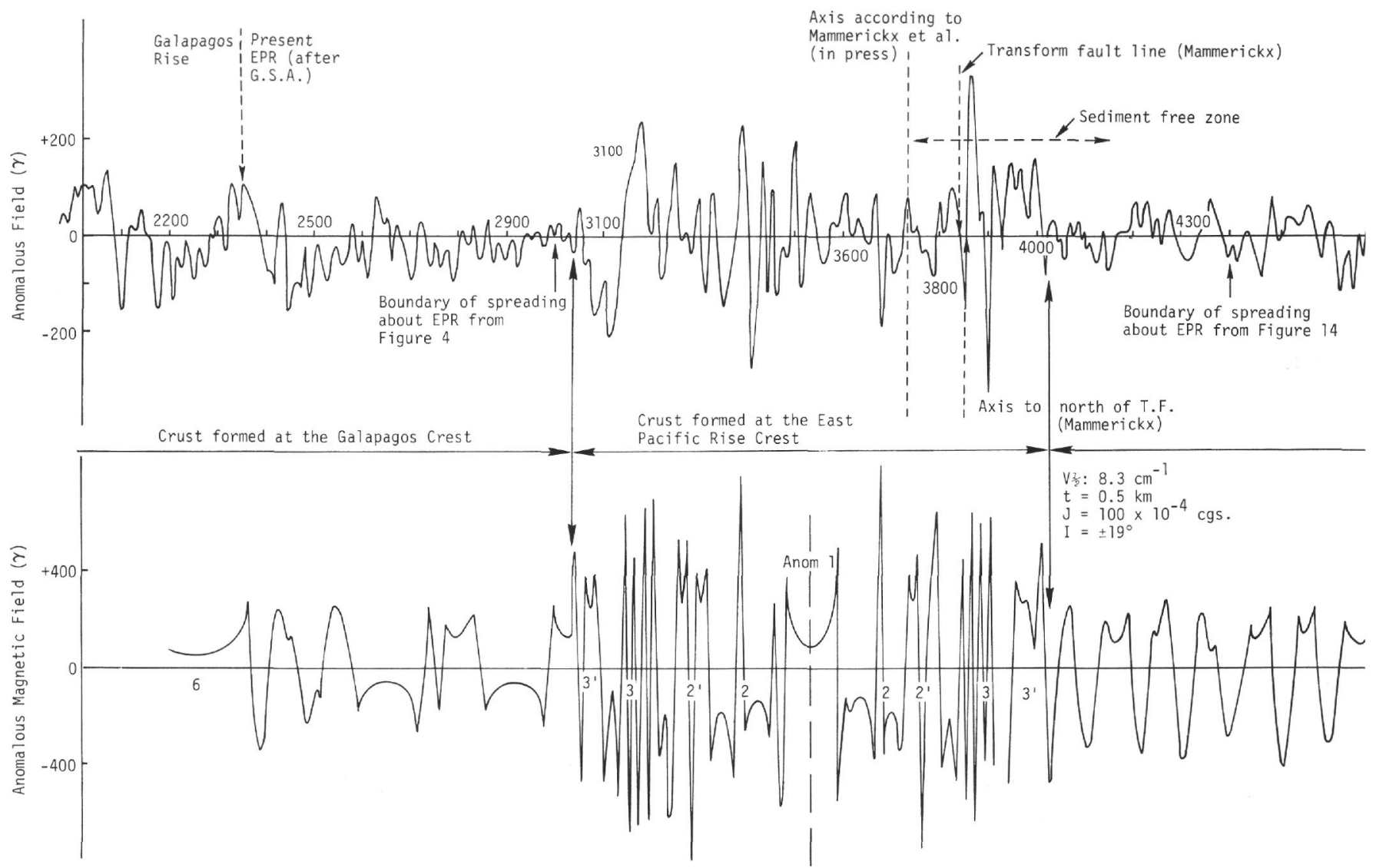

Figure 11. Observed and synthesized magnetic anomaly fields over the East Pacific Rise crest, the Bauer Deep, and the Galapagos Rise crest.

this segment, $650 \gamma$ peak to peak at $3900 \mathrm{~km}$, with a major east-west transform offset of the rise crest, as shown by Mammerickx et al. (1975). For purposes of comparison, the synthetic profile of Figure $11 \mathrm{~b}$ has been generated with a factor of two greater magnetization for East Pacific Rise crust than for the fossil rise (Galapagos) crust.

A second petrologic contrast mechanism for the change in anomaly levels invokes a high proportion of FeTi-rich lavas in the 3050 to $4020 \mathrm{~km}$ segment. This class of mid-ocean-ridge basalts is widely distributed in the Pacific and, if the factor two contrast in oxide content and magnetic intensity between the Site 321 basalts (FeTi) and the Site 319 basalts is typical, they are quite capable of producing the enhanced magnetic anomaly amplitudes.

The shorter average wavelength of anomalies in the 3050 to $4020 \mathrm{~km}$ interval is most readily explained in terms of spreading rate differences. Following Herron (1972) we have taken a spreading half rate of 8.3 $\mathrm{cm} / \mathrm{yr}$ for the East Pacific Rise crustal section. A very similar value is suggested by Rea (personal communication) for the latitude at which the EPR has crossed. However, it should be remembered that no specific anomaly correlation allows this figure to be checked, and that the Sclater-Francheteau model curve for 12.3 $\mathrm{cm} / \mathrm{yr}$ of Figure 12 fits the bathymetry very closely. In order to account for an age difference of 7 to 10 m.y. between the Galapagos Rise crest and the boundary of
East Pacific Rise crust, as indicated in Anderson and Halunen (1974), a Galapagos Rise spreading rate of 16.6 $\mathrm{cm} / \mathrm{yr}$ is required. This has been used in the synthetic profile)of Figure $11 \mathrm{~b}$ and the anticipated difference in anomaly wavelength between the different crustal segments is apparent. If account is taken of apparent basement age at Site 319 and the Sclater-Francheteau profiles for the Galapagos Rise, a rather lower spreading rate of 10 to $12 \mathrm{~cm} / \mathrm{yr}$ would suffice. A relatively small spreading rate difference in favor of the Galapagos Rise would be consistent with the difference in anomaly wavelengths being less marked than the difference in anomaly amplitudes.

Figure 13 shows the observed anomaly profile from 5600 to $7200 \mathrm{~km}$, that is, over the crustal segment generated at the Galapagos Rise and lying to the north of the Mendaña Fracture Zone. This profile terminates at Site 320, where paleontological evidence indicates a basement age within the 26-30 m.y. B.P. interval. Using this age and spreading rates indicated from the anomaly spacing of Figure 1, a synthetic profile has been generated for comparison with the observed profile. An attempt at correlating the two profiles is shown in Figure 13. Correlation is based on forcing the profiles to fit at Site 320, where basement age is assumed to be known, and over the $6300-6600 \mathrm{~km}$ interval where the generally slightly negative anomaly is associated with the long period of reverse geomagnetic polarity between 25.43 and 26.86 m.y. B.P. This match should be seen 


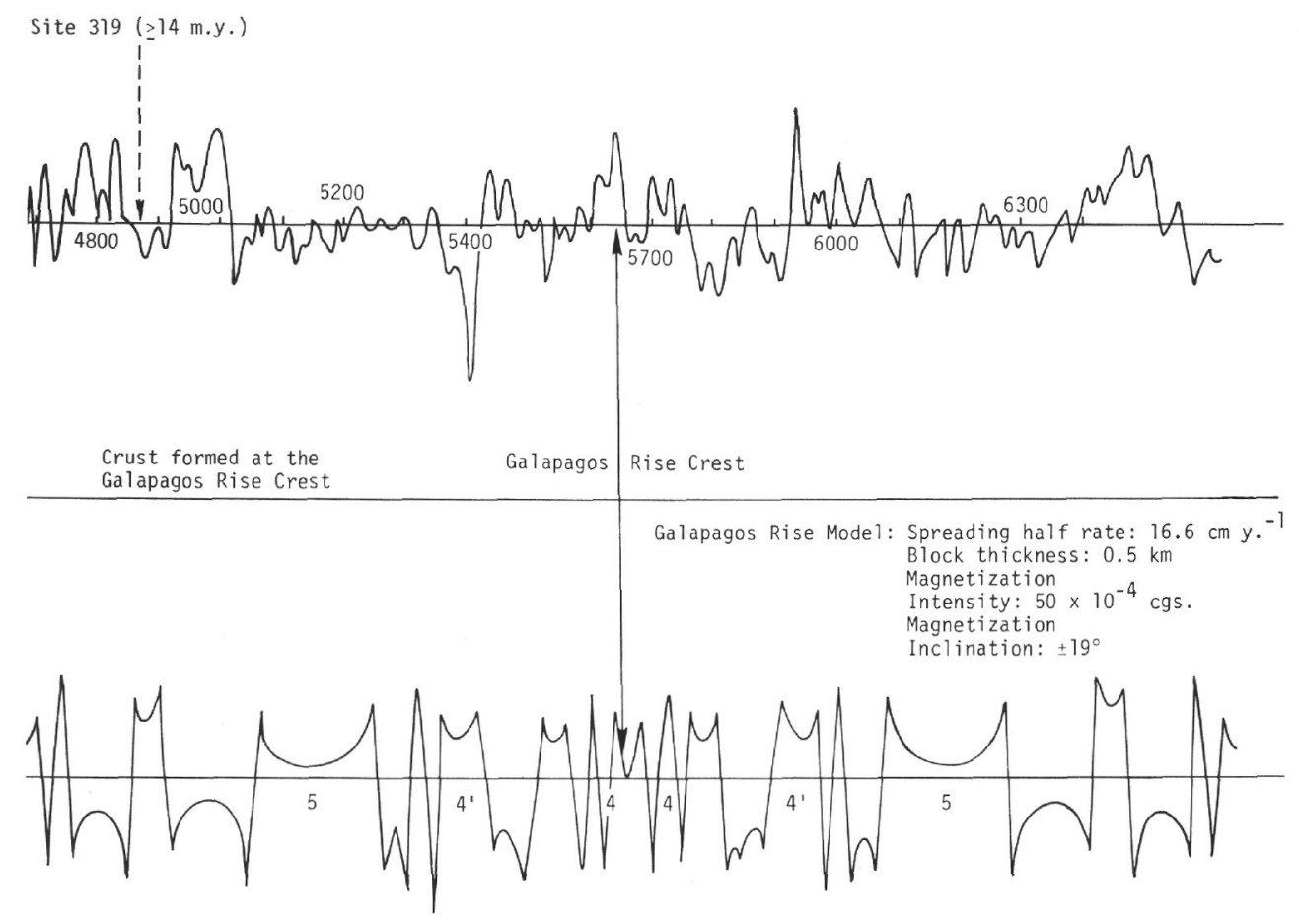

Figure 11. (Continued).

more as indicative of the difficulties of correlation at low latitudes rather than as independent information on crustal age along the profile. Consider the long reverse geomagnetic polarity interval referred to above; at magnetic latitudes where the vertical component of magnetization dominates the anomaly $\left(>30^{\circ} \mathrm{N}\right.$ or S), this polarity interval would result in a broad strong negative magnetic anomaly which should be readily identifiable. At the latitude of the survey, close to $10^{\circ} \mathrm{S}$, rocks magnetized during this polarity interval produce a broad zone characterized by negligible external magnetic anomaly expression. Identification of this zone in practice is hazardous as such perturbing effects as topography variation and variation in magnetic properties of the magnetic anomaly source rocks are sufficiently large to obscure partly the anticipated anomaly form.

Figure 14 shows the observed magnetic anomaly profiles along the two remaining segments of the track, from Site 321 (Figure 14a) and from Site 321 to the continental shelf near Callao, Peru (Figure 14b).

Between Sites 320 and 321 the two major magnetic effects observed are closely associated with the two major fracture zones crossed on this segment of the track. The senses of the magnetic anomalies suggest that at the northern fracture zone at $7320 \mathrm{~km}$ the track passed from strong reversely magnetized crust onto strong normally magnetized crust and vice versa at the southern fracture zone at $7500 \mathrm{~km}$.

The track segment from Site 321 to Callao (Figure 14b) starts with a positive anomaly, identified as number
16 on Figure 1 and confirmed by the apparent basement age of close to $40 \mathrm{~m} . \mathrm{y}$. at Site 321 . The other feature of interest on this segment is the continuation of short wavelength, typical oceanic, magnetic anomalies for 50 $\mathrm{km}$ landwards of the trench axis. Beyond this distance only a longer wavelength type of anomaly is seen. Here then, the magnetic expression of oceanic basement indicates its coherent extension, without significant increase in depth, for at least $50 \mathrm{~km}$ beneath the landward wall of the trench, against a minimum extension of only $1 \mathrm{~km}$ seen on the refelction profiling record (of Figure 7). Thus the magnetic anomaly evidence enhances the case for the reality of the subduction process at this location.

\section{OCEANIC BASEMENT DEPTH AND AGE}

Since magnetic anomalies provide little indication of oceanic basement age along the track, it may be useful to employ the relationship between depth, spreading rate, and basement age first quantified by Sclater and Francheteau (1970). Figure 12 shows the bathymetry along the track of Glomar Challenger from the point at which the Tuamotu Rise-East Pacific Rise boundary was crossed to Site 320 . This part of the track is clearly divided into a number of segments, in which water depth varies smoothly with distance, suggesting that the theoretical relationship can be fitted, separated from each other by steps or sharp breaks in gradient. These segments are: 


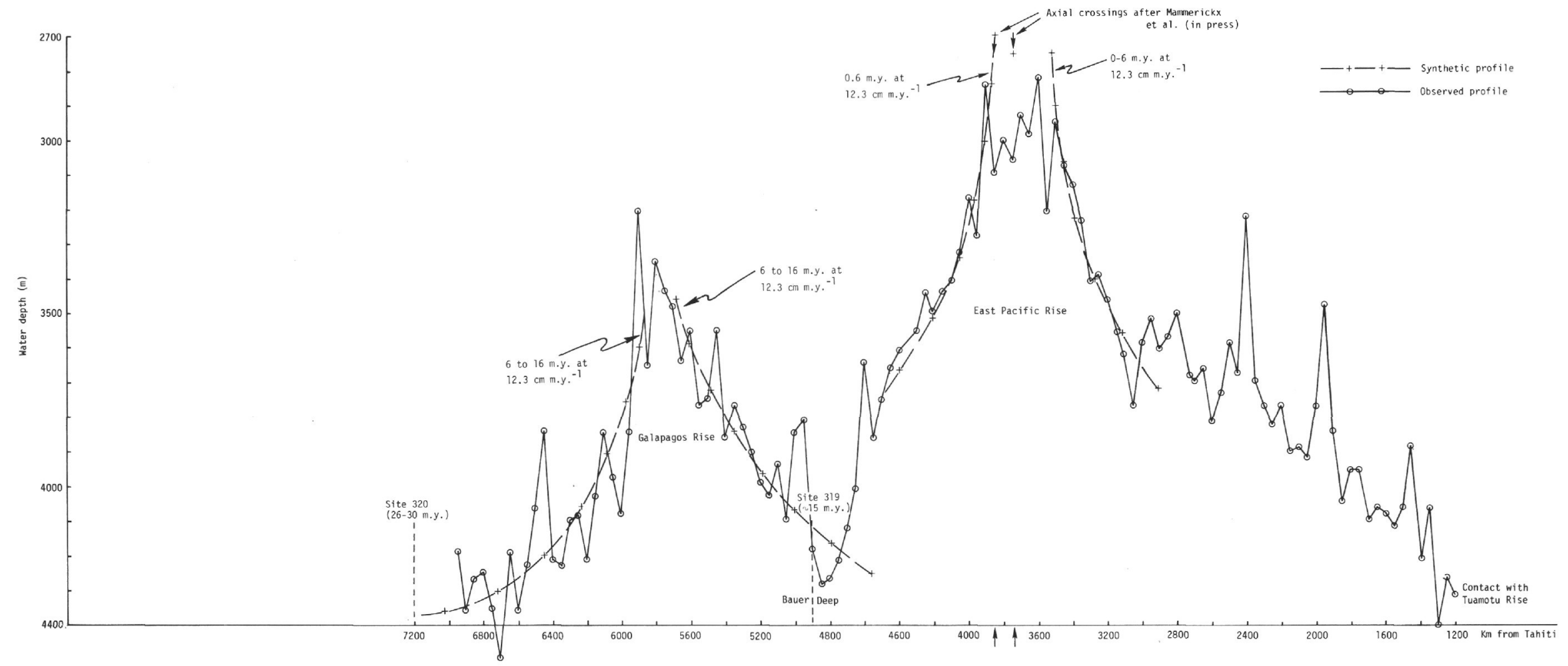

Figure 12. Bathymetry along the track of DSDP Leg 34 (point values plotted every $50 \mathrm{~km}$ ) with Sclater-Francheteau model profiles fitted to the crests of the East Pacific and Galapagos rises. 
(i) 1200-3000 km: Crustal segment possibly formed at the Galapagos Rise crest;

(ii) $3000-4400 \mathrm{~km}$ : Crust formed at the East Pacific Rise crest;

(iii) $4400-4800 \mathrm{~km}$ : A crustal segment (the Bauer Scarp) grading anomalously steeply to the east that may mark the eastern boundary of the actively spreading East Pacific Rise (Anderson and Sclater, 1972; Rea, in press); and

(iv) $4800-7200 \mathrm{~km}$ : Crust formed at and including the crest of the Galapagos Rise.

Segment (i) is thought to be between 16 to 47 m.y. in age (Figure 1, etc), that is, it represents crust formed at the crest of the Galapagos Rise, and now separated from the rise crest by the presently active East Pacific Rise.

The 1400-km-long crustal segment (ii) containing the presently active East Pacific Rise crest can be modeled rather exactly using a spreading rate of $12.3 \mathrm{~cm} / \mathrm{yr}$ and a time interval of 0-6 m.y. We should note, however, that to fit the theoretical relationship on the western flank of the rise requires displacement of the spreading axis westwards by approximately $200 \mathrm{~km}$ from its supposed location to the south of the transform offset shown in Mammerickx et al. (1975). The presence of significant sediment cover at the predicted location indicates that the theoretical curve wrongly predicts the position of the rise axis. On the eastern flank of the East Pacific Rise the theoretical relationship fits well with the observed water depth profile and predicts fairly accurately the position of the rise crest to the north of the transform offset. The spreading rate assumed in modeling the profile of the East Pacific Rise crest is close to $50 \%$ higher than the rate indicated by magnetic anomaly identification. This may not be a serious drawback since both anomaly identification is demonstrably uncertain in this area and, for high spreading rates, rather large change in spreading rate appears to produce relatively small change in profile form.

Segment (iii) has been identified elsewhere on the boundary of the East Pacific Rise and the Bauer Deep (Anderson and Halunen, 1974; Rea, in press) and presumably originates in the sharp contact between relatively hot, young East Pacific Rise crust and old, colder Galapagos Rise crust. Magnetic anomaly amplitude evidence suggests that it is Galapagos Rise crust, presumably reheated and re-elevated by the rise jumping process of 6 to 9 m.y. B.P. The part of crustal segment (iv) from the crest of the Galapagos Rise to the Bauer Deep has been interpreted as being generated continuously during the last part of the period of activity at the Galapagos Rise crest, and it is possible to fit a theoretical curve for the interval 6 to 16 m.y. to this segment. The basement age at Site 319 agrees quite reasonably with the prediction of the model. However, spreading rates are somewhat higher than those obtained from basement ages at Sites 319 and 320, together with the assumption that spreading on the Fossil Rise terminated 6 m.y. ago. The eastern flank of the Galapagos Rise may also be modeled rather exactly, but with an apparent spreading rate well in excess of the rate indicated by basement age at Site 320 .

This attempt to fit Sclater-Francheteau profiles to oceanic basement along the track focuses attention on several apparently anomalous features, some of which have been noted by Mammerickx et al. (1975). In particular (a) the crustal segment, (i) above, separating the East Pacific Rise and the Tuamotu Rise, and possibly generated at the Galapagos Rise, is too shallow for its supposed age. In this respect it is one of the largest areas of anomalous oceanic crust known. (b) This same segment is gently convex upwards, instead of being concave, as the simple model requires. (c) The segment is uniformly covered with sediment, although an age difference from east to west of 30 m.y. is supposed. (d) Galapagos Rise crust in the Bauer Deep is too deep for its apparent age and is about 650 meters deeper than crust of supposedly similar age is directly to the east of the East Pacific Rise. (e) To fit a Sclater-Francheteau curve to the west flank of the Galapagos Rise crest requires marked counter-clockwise rotation of the curve.

No simple, one-stage ridge migration model for the thermal history and present thermal regime in this area can account for all of these features. The convexity and uplift of the segment of Galapagos Rise crust to the west of the East Pacific Rise appears to require a thermal source located beneath the segment. The rather sparse heat flow data in this area apparently do not support the presence of such a source (Mammerickx et al., 1975). However, incomplete rise migration to a more westward location might produce thermal expansion of the lower part of the plate, and the observed large area of shallow crust, well before heat loss at the surface of the plate departs from normal oceanic values. The poor fit of observed and expected magnetic anomalies over this segment, together with the other anomalous features, suggest that a test of basement age and nature by drilling would be valuable here.

The apparently excessive depth of the Bauer Deep, together with the rotation of the depth curve to fit the observed profile, are not readily explained. There is some evidence that the basement at Site 319 is significantly older than the age of the lowest sediments (Reynolds, this volume; Seidemann, this volume), but the uncertainties associated with the radiometric ages are sufficiently large to include the paleontological ages. A single fission track age (Mitchell and Aumento, this volume) agrees with the paleontological age.

It seems that the attempt to apply the SclaterFrancheteau relationship in this area is most valuable in identifying regional structural breaks and problem areas.

\section{EVIDENCE FOR ELASTIC FLEXURE OF THE OCEANIC CRUST}

Several bathymetric entities along the track have features indicative that elastic (or visco-elastic) flexure of the crust is taking place. These features are moats and arches adjacent to obvious local crustal loads such as several large seamounts and the continental margin. These features are illustrated in Figures 15 and 16, with numerical properties given in Table 1 .

Proper analysis of these features requires areal surveying, preferably with gravity profiles in addition to bathymetry and sediment thickness. However, it is possible, even with data from a single track, to carry out 


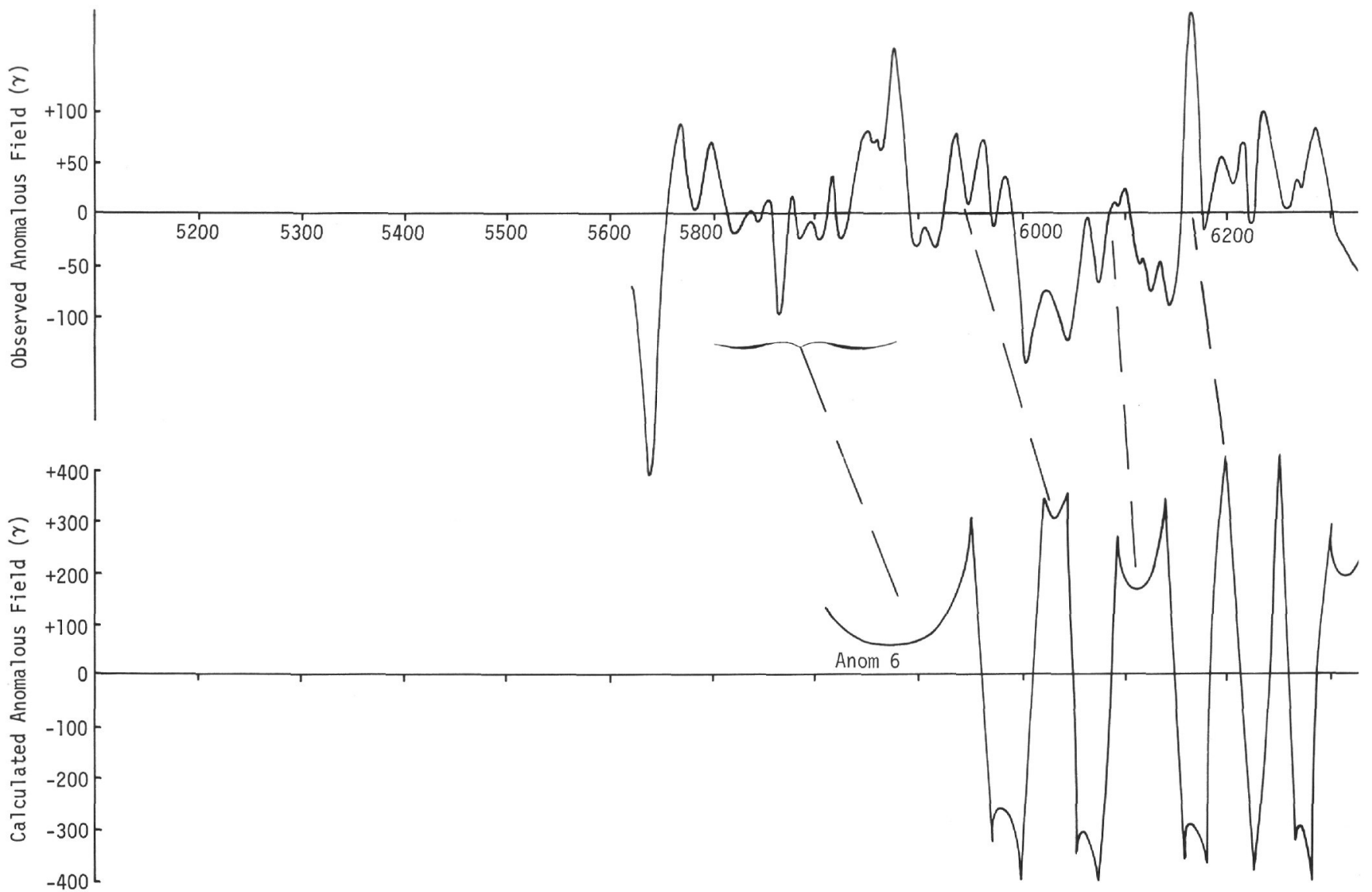

Figure 13. Observed and synthesized magnetic anomaly fields over the eastern flank of the Galapagos Rise to Site 320.

some simple but interesting calculations regarding the elastic properties of the oceanic crust as a whole in the vicinity of the load.

Following Gunn (1943), Walcott (1970), and others, the wavelength of the deformation of the lithosphere in the vicinity of a point load can be expressed by

$$
\alpha_{4}=\frac{E h^{3}}{3\left(1-\epsilon^{3}\right) \delta p g}
$$

where $\alpha$ is the flexural parameter (Walcott, 1970), or, alternatively, flexural rigidity, $D$, of Watts and Talwani (1974); $E$ is Young's modulus (taken as $0.8 \times 10^{12} \mathrm{cgs}$ units); $h$ is the thickness of the crust that deforms elastically; $\epsilon$ is Poissons Ratio (taken as 0.25 ); $\delta \mathrm{p}$ is the density difference between the material underlying and overlying the linearly elastic beam (taken as $2.3 \mathrm{~g} / \mathrm{cm}$ ), and $\mathrm{g}$ is the average gravity.

From our limited data it is both sensible and interesting to obtain values of $h$, assuming the standard values for $E$, $\epsilon$, and $\delta \mathrm{p}$. The interest lies in determining the fractional thickness of the Nazca and Pacific plates, which we may take as being $100-150 \mathrm{~km}$ in thickness, that deform elastically. In order to determine $h$ we must find $\alpha$. From our single-track profiles $\alpha$ is most exactly obtained from the distance between the point or line or application of the load to the crest of the adjoining deformation arch (Figures 15 and 16). No estimate of the mass of the load is required if this method is used.
For the three seamounts illustrated in Figure 15, adjacent crustal arching may be present for the seamount shown in Figures $15 \mathrm{~b}$ and $15 \mathrm{c}$. Arching is clearly present for the ocean crust adjacent to the Peru-Chile Trench illustrated in Figure 16.

If the seamounts illustrated in Figure 15 are taken as applying point loads to the oceanic crust at the point corresponding to their apices, then the flexural parameter, $\alpha$, can be obtained from the relationship

$$
\alpha=\frac{4 x_{b}}{3 \pi}
$$

where $x_{b}$ is the distance from the point of application of the load to the crest of the arch. For the seamounts of Figure 15 the load-arch crest distance varies from 44.5 to $53.5 \mathrm{~km}$ which leads to values of $h$ from 4.7 to $6.9 \mathrm{~km}$ or only $3 \%$ to $5 \%$ of the present plate thickness (Table 1 ). These values are significantly lower than the values obtained for other loads on the crust. For example, for Hawaii the thickness of the lithospheric plate that deforms elastically is close to $30 \mathrm{~km}$ (Watts and Cochran, 1974) while loading of the continental crust indicates that an even greater crustal thickness deforms elastically (Watts, personal communication).

Figure 16 shows that arching of the oceanic crust adjacent to the Peru-Chile Trench has a much larger wavelength than the arching adjacent to the seamount loads. Assuming the situation can be modeled by a semi- 


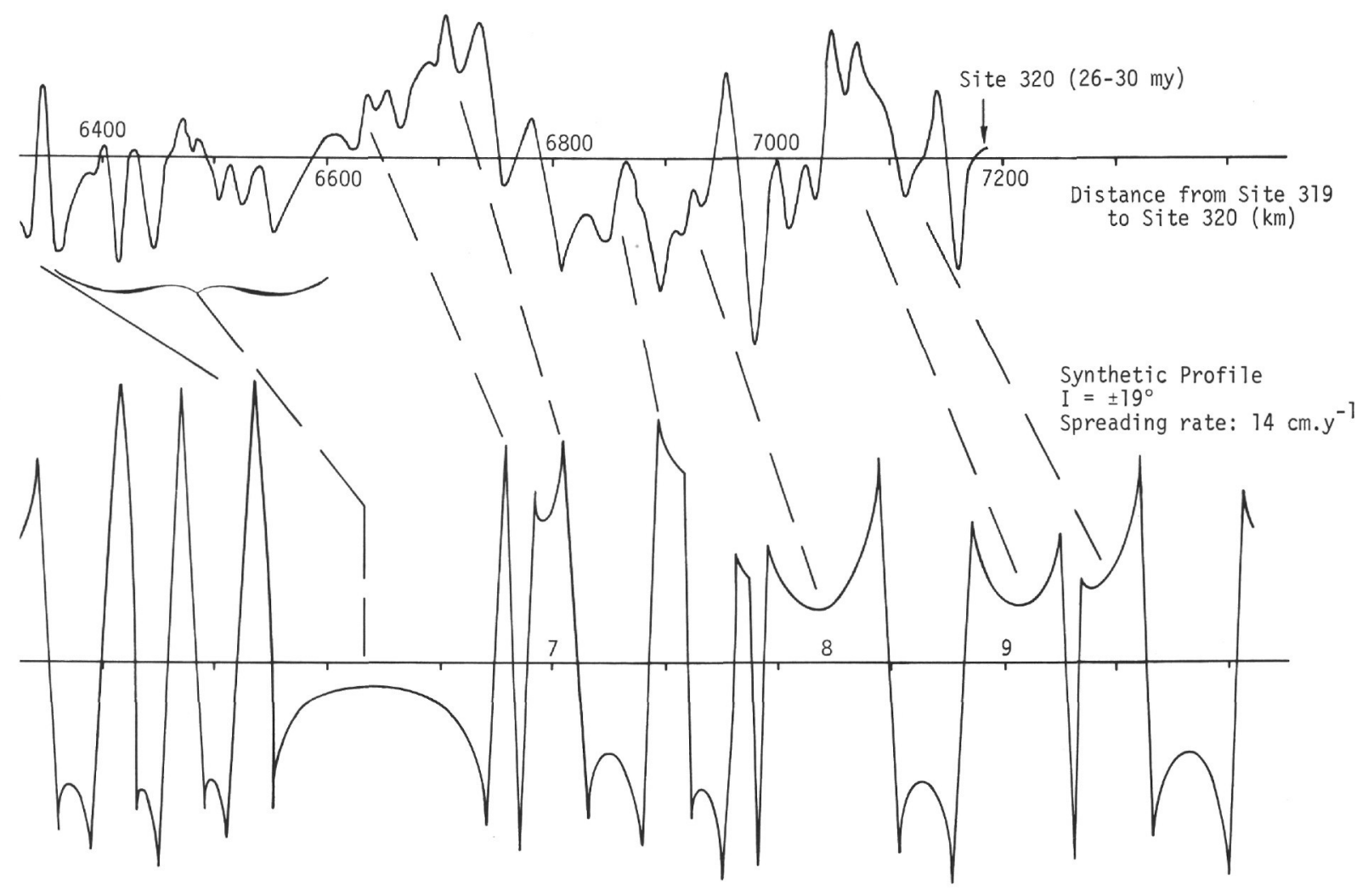

Figure 13. (Continued).

infinite beam experiencing a point load and following Watts (personal communication) and Watts and Talwani (1974), we have for the flexural rigidity:

$$
D=\frac{64 \delta \operatorname{pg} x_{b}^{4}}{81 \pm 4}
$$

For $x_{b}=194 \pm 9 \mathrm{~km}$ (Figure 16) we have $D=2.10 \times$ $10^{30}{ }_{b}$ dyne $\mathrm{cm}$, and for the effective elastic layer thickness, $T$, ( $h$ of Walcott, 1970)

$$
T=3 \sqrt{ } \frac{\left(12 D\left(1-\sigma^{2}\right)\right.}{E}
$$

With $\sigma=0.25$ and $E=0.8 \times 10^{12}$ we have $T=31 \pm 2$ $\mathrm{km}$, or a factor of six greater than the seamount values.

If the seamount values of $h$ are reliable, that is, that arches have been correctly identified, we are faced with the problem of the relatively low values obtained. A simple model can be proposed which is capable of explaining the seamount, trench and other values of $h$ for oceanic and continental crustal loading. In this model the fraction of the plate that deforms elastically increases with time, that is, as the plate cools with increasing distance from accretional boundaries. For this model to account for the thin elastically deforming crustal layer in the vicinity of the seamounts, it will probably be necessary to assume that seamount forma- tion took place near a ridge crest, where plastic deformation is likely to take place at very shallow depths. If this is the case, the seamounts provide measures of the thickness of the elastically deforming crust of different locations and times from the values at their present sites, where rather thicker layers are likely to exist. In contrast, oceanic crust at the Peru-Chile Trench, at approximately $45 \mathrm{~m} . \mathrm{y}$. age, is presently experiencing elastic deformation while in a thermal state consistent with its age. All other oceanic and continental features studied represent the loading of relatively old crust. For example the Hawaiian volcanoes rest and deform oceanic crust, which, with the exception of the immediate vicinity of the volcanic conduits, is in a thermal and elastic state consistent with its age of 80 to 110 m.y.

\section{SUMMARY AND DISCUSSION}

Consideration of the DSDP Leg 34 underway survey data puts constraints on the environments of the three drill sites $(319,320$, and 321). All are located within oceanic crust generated at the crest of the Galapagos Rise, now within the Nazca plate. This conclusion is most important for Site 319, which lies in the Bauer Deep between the Galapagos and East Pacific rises. Although magnetic anomalies do not give an independent estimate of crustal age at Site 319, the sharp change in magnetic anomaly character at $4020 \mathrm{~km}$ puts Site 319 , at $4900 \mathrm{~km}$, well within an area of crust generated at the Galapagos Rise. 


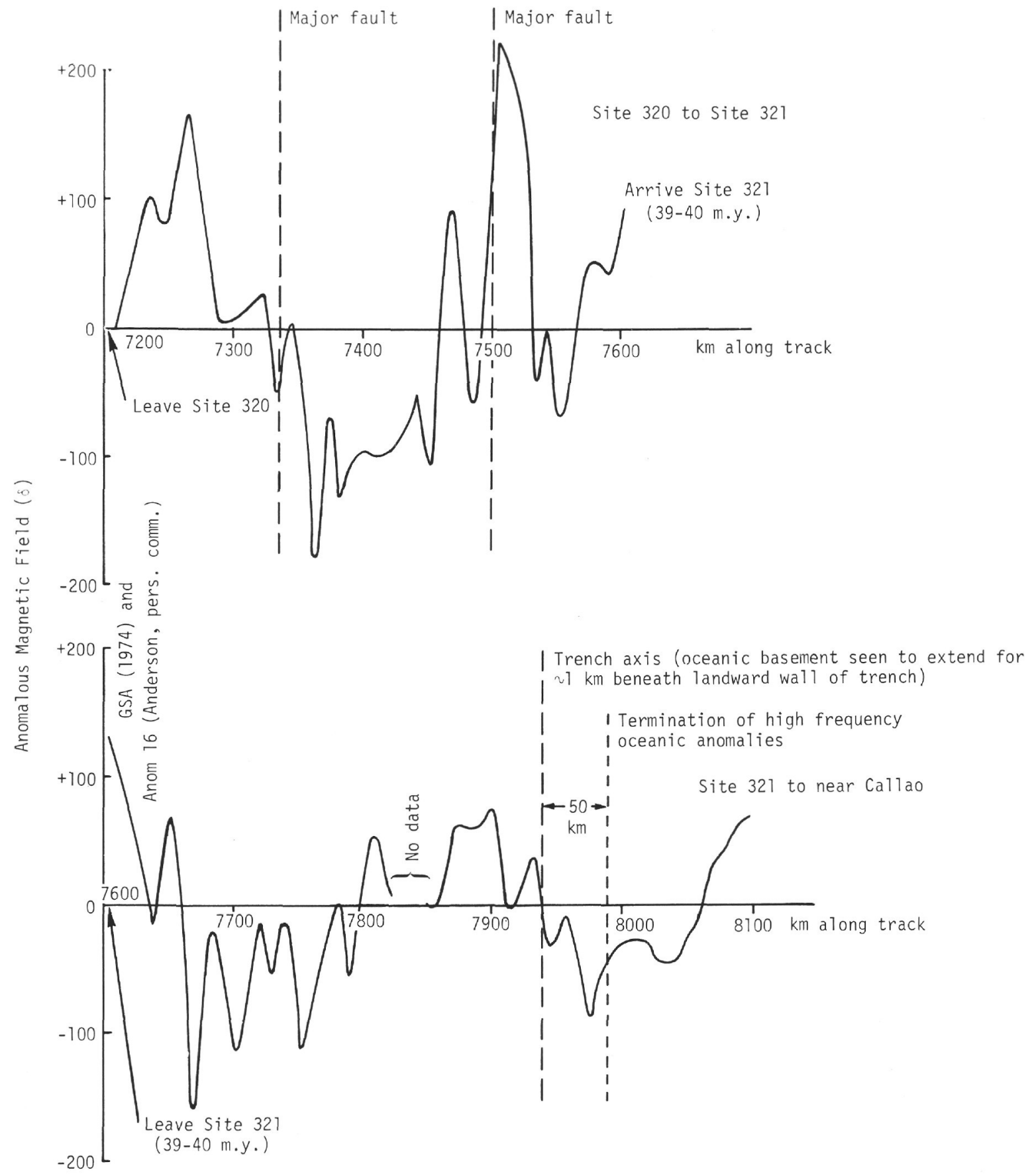

Figure 14. Observed magnetic anomaly field from Site 320 to Site 321 and from Site 321 to the continental shelf off Peru.

The explanation proposed for the difference in anomaly amplitude between adjacent East Pacific Rise and Galapagos Rise crusts at 3050 and $4020 \mathrm{~km}$ is one of the two novel results of this analysis of the Leg 34 underway survey data. It seems that very important structural information may be obtained from magnetics in equatorial latitudes (and elsewhere) even where individual anomalies cannot be identified. Any sudden change in general anomaly amplitude should be looked on as the site of a possible temporal discontinuity. Conversely, anomaly amplitude change across a welldated discontinuity can be used to monitor the decay of magnetization with time in oceanic basement as a result of low temperature seawater alteration.

The other novel result concerns the thickness of the upper crustal layer that deforms elastically rather than plastically in the vicinity of three Galapagos Rise seamounts. Values at close to $5 \mathrm{~km}$ (or $3 \%$ to $5 \%$ of the present plate thickness) are the lowest recorded anywhere and may be relics of attenuated crustal conditions during spreading from the Galapagos Rise crest, the seamounts with their moats and arches being transported away by rapid spreading on this rise to their present positions. 
TABLE 1

Numerical Properties of the Seamounts

\begin{tabular}{|c|c|c|c|c|c|c|c|}
\hline Feature & $\begin{array}{l}\text { Regional } \\
\text { Water } \\
\text { Depth } \\
\text { (m) }\end{array}$ & $\begin{array}{l}\text { Estimated } \\
\text { Crustal } \\
\text { Age (m.y.) }\end{array}$ & $\begin{array}{l}\text { Depth of } \\
\text { Moat (m) }\end{array}$ & $\begin{array}{l}\text { Height of } \\
\text { Seamount } \\
(\mathrm{m})\end{array}$ & $\begin{array}{l}\text { Estimated } \\
\text { Vol. of } \\
\text { Seamount } \\
\left(\mathrm{km}^{3}\right)\end{array}$ & $\begin{array}{c}\text { Distance to } \\
\text { Arch Crest } \\
(\mathrm{km}) \text { (Average) }\end{array}$ & $\begin{array}{l}\text { Thickness of } \\
\text { Effective } \\
\text { Elastic Layer } \\
(\mathrm{km})\end{array}$ \\
\hline $\begin{array}{l}\text { Seamount, } 1100 \mathrm{Z} \\
4 \mathrm{Jan} .74 \\
\text { (4770 km) } \\
\text { "Party Chief } \\
\text { Seamount" } \\
\text { (Fig. 15a) }\end{array}$ & 4139 & 15 & 144 & 1124 & 294 & $45,44(44.5)$ & $4.7^{\mathrm{a}}$ \\
\hline $\begin{array}{l}\text { Seamount, } 1730 \mathrm{Z} \\
18 \mathrm{Jan} .74 \\
(5690 \mathrm{~km}) \\
\text { (Fig. } 15 \mathrm{~b})\end{array}$ & 3509 & 9 & 157 & 2125 & 524 & $54,53(53.5)$ & $6.0^{\mathrm{a}}$ \\
\hline $\begin{array}{l}\text { Seamount, } 0200 \mathrm{Z} \\
30 \mathrm{Dec} .73 \\
(3070 \mathrm{~km}) \\
\text { (Fig. } 15 \mathrm{c})\end{array}$ & 3554 & $6-16^{b}$ & 207 & 1737 & 396 & $53,45(49.0)$ & $5.3^{\mathrm{a}}$ \\
\hline $\begin{array}{l}\text { Peru Chile } \\
\text { Trench } \\
(7950 \mathrm{~km}) \\
\text { (Fig. 16) }\end{array}$ & $\begin{array}{l}4450 \\
\text { (for } \\
\text { oceanic } \\
\text { crust) }\end{array}$ & 45 & $\begin{array}{c}1330 \\
\text { (depth of } \\
\text { trench axis } \\
\text { below oceanic } \\
\text { crustal depth) }\end{array}$ & $\begin{array}{c}5780 \\
\text { (thickness } \\
\text { of shelf } \\
\text { above trench } \\
\text { axis datum) }\end{array}$ & $\begin{array}{l}\text { (two dimen- } \\
\text { sional load) }\end{array}$ & $\begin{array}{l}194 \text { (measured } \\
\text { normal to } \\
\text { trench axis }\end{array}$ & $31 \pm 2^{\mathrm{C}}$ \\
\hline
\end{tabular}

\section{ACKNOWLEDGMENTS}

Careful collection of the data analyzed in this chapter was the responsibility of Mike Lehman and the other DSDP technicians present on Glomar Challenger during Leg 34. Many colleagues have aided in preparing and checking this report, they are, in no special order: Anthony Watts, R.I. Walcott, Robert Yeats, Pat Barnes, Pat Ryall, Ferenć Stefani, Michael Keen, Jacqueline Mammerickx, Peter Lonsdale, Mary-Ann Annand, Monika Michaelis, and David Rea. I would like to thank them all. The underway data processing group at Scripps Institution of Oceanography provided much valuable data and the illustrating staff at DSDP prepared the diagrams.

\section{REFERENCES}

Anderson, R.N. and Halunen, J., 1974. Implications of heat flow for metallogenesis in the Bauer Deep: Natu.e, v. 251, p. 473-475.

Anderson, R.N. and Sclater, J.G., 1972. Topography and evolution of the East Pacific Rise between $5^{\circ} \mathrm{S}$ and $20^{\circ} \mathrm{N}$ : Earth Plant. Sci. Lett., v. 14, p. 433-441.

Chase, R.L. and Bunce, E.T., 1969. Underthrusting of the eastern margin of the Antilles by the floor of the western North Atlantic Ocean, and the origin of the Barbados Ridge: J. Geoph. Res., v. 74, p. 1415-1420.

Edmond, J.M., 1974. On the dissolution of carbonate and silicate in the deep ocean: Deep-Sea Res., v. 21, p. 455-480.

Gunn, R., 1943. A quantitative evaluation of the influence of the lithosphere on the anomalies of gravity: J. Franklin Inst., v. 236 , p. 373.

Hays, J.D. et al., 1972. Initial Reports of the Deep Sea Drilling Project, Volume 9: Washington (U.S. Government Printing Office)

Heirtzler, J.R., Dickson, G.O., Herron, E.M., Pitman, W.C., and LePichon, X., 1968. Marine magnetic anomalies, geomagnetic field reversals and motions of the ocean floor and continents: J. Geoph. Res., v. 73, p. 2119-2136.

Herron, E.M., 1972. Sea-floor spreading and the Cenozoic history of the east-central Pacific: Geol. Soc. Am. Bull., v. 83, p. 1671-1692.

Holmes, M.L., Von Huene, R., and McManus, D.A., 1972. Seismic reflection evidence supporting underthrusting beneath the Aleutian Arc near Amchitka Island: J. Geoph. Res., v. 77, p. 959-964.

Irving, E., Park, J.K., Haggerty, S.E., Aumento, F., and Loncarevic, B., 1970. Magnetism and opaque mineralogy of basalts from the Mid-Atlantic Ridge at $45^{\circ} \mathrm{N}$ : Nature, v. 228 , p. $974-976$.

Mammerickx, J., Anderson, R.N., Menard, H.W., and Smith, S.M., 1975. Morphology and tectonic evolution of the eastcentral Pacific. Geol. Soc. Am. Bull. v. 86., p. 111-118.

Morgan, W.J., 1972. Plate motions and deep mantle convection. Geol. Soc. Am. Mem. 132. P. 7-27.

Pautot, G. and Dupont, J., 1974. La zone de fracture des Marquises, C.R. Acad. Sci. Paris, v. 279, p. 1519-1521.

Rea, D.K., in press. An analysis of a fast spreading rise crest: The East Pacific Rise, $9^{\circ}$ to $12^{\circ}$ South: Geol. Soc. Am. Bull.

Schlanger, S.O., Jackson, E.D., et al., 1974. Leg 33, Deep Sea Drilling Project: Testing a hot-spot theory: Geotimes, v. 18, p. 16-20.

Sclater, J.G. and Francheteau, J., 1970. The implications of terrestrial heat flow observations on current tectonic and geochemical models of the crust and upper mantle of the Earth: Geophys. J., v. 20, p. 509-542.

Walcott, R.I., 1970. Flexure of the lithosphere at Hawaii: Tectonophysics, v. 9, p. 435-446.

Watts, A.B. and Cochran, J.R., 1974. Gravity anomalies and flexure of the lithosphere along the Hawaiian-Emperor seamount chain: Geoph. J., v. 38, p. 119-142.

Watts, A.B. and Talwani, M., 1974. Gravity anomalies seaward of deep sea trenches and their tectonic implications: Geoph. J., v. 36, p. 57-90. 

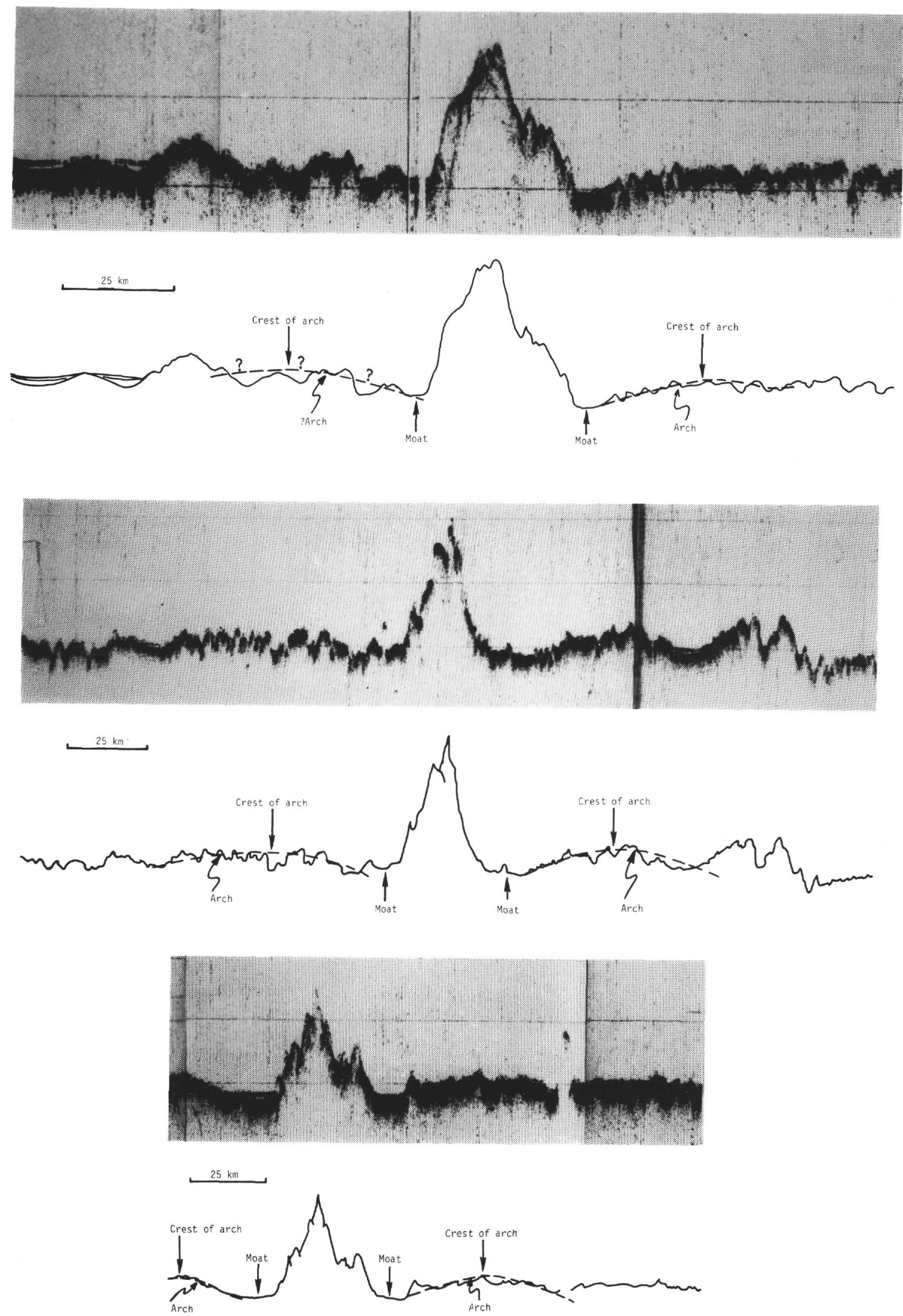

Figure 15. Profiles across three seamounts showing moats and arches resulting from the elastic deformation of the underlying crust. 

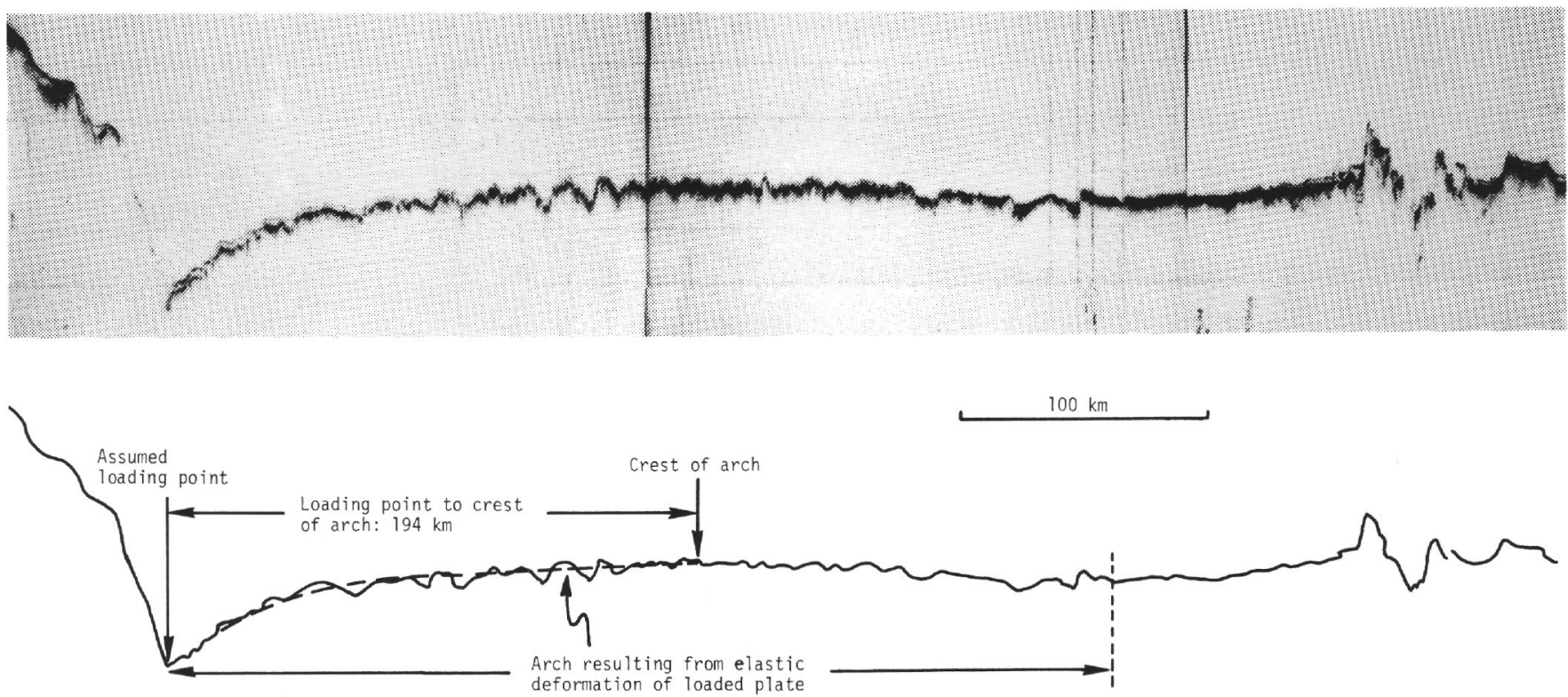

Figure 16. Profile across the Peru-Chile Trench and its environs showing arching of the oceanic crust resulting from elastic deformation. 